\title{
IMPLIKASI MANAJEMEN SUMBER DAYA MANUSIA BERBASIS NILAI NILAI ISLAMI (STUDI PADA BANK MUAMALAT PALOPO)
}

\author{
1Muzayyanah Jabani ${ }^{2}$ Tadjuddin \\ 1,2 Institut Agama Islam Negeri (IAIN) Palopo \\ E-mail: muzayyanah jabani@iainpalopo.ac.id
}

\begin{abstract}
This research analyzes the implication of human resourcrces management based on Islamic values in Bank Muamalat Palopo. The kind of the research is qualitative study. Based on the result of the research, the implication of human resourcrces management based on Islamic values in Bank Muamalat Palopo has involved the Islamic values. It is applied through: a. the recruitment and selection done by considering the result of syariah selection; $b$. the development of officers is always done by the management of Bank Muamalat and realized in the form of training/workshop; c. the application of working assessment and officers' compensation which usually given in the form of reward to the officer who achieves a particular target can improve the officers' motivation; d. industrial relation is managed directly by Bank Muamalat central.
\end{abstract}

Keywords: implication, human resources management, Islamic values

\begin{abstract}
Abstrak
Penelitian ini menganalisis mengenai implikasi konsep Manajemen Sumberdaya Manusia (MSDM) berbasis nilai-nilai Islami pada perusahaan perbankan syariah dalam hal ini Bank Muamalat Palopo. Jenis penelitian yang digunakan dalam penelitian ini adalah penelitian kualitatif yaitu penelitian yang menghasilkan prosedur analisis yang tidak menggunakan prosedur analisis statistik atau dengan menggunakan cara kuantifikasi. Berdasarkan hasil yang diperoleh, implikasi MSDM Islami pada Bank Muamalat khususnya di kota Palopo telah melakukan atau melibatkan manajemen sumberdaya yang bernilai Islami atau yang sesuai dengan nilai-nilai Islami. Hal itu diterapkan pada: a. perekrutan dan seleksi yang dilakukan oleh Bank Muamalat Palopo dilakukan dengan mempertimbangkan hasil seleksi syariah; $b$. pengembangan karyawan selalu dilakukan oleh pihak manajemen Bank Muamalat dan diwujudkan dengan memberikan training/pelatihan kepada para karyawan; c. penerapan penilaian kinerja dan kompensasi karyawan merupakan hal yang dapat meningkatkan motivasi bagi karyawan, hal tersebut biasa berbentuk pemberian reward atau penghargaan kepada karyawan yang mencapai target tertentu; $d$. hubungan industrial diatur secara langsung oleh pihak Pusat Bank Muamalat.
\end{abstract}

Kata Kunci,: implikasi, manajemen sumber daya manusia, nilai-nilai Islami

\section{PENDAHULUAN}

Organisasi adalah sekumpulan orang yang memiliki tujuan bersama dan bekerja sama untuk mencapai tujuan tersebut. Organisasi merupakan sebuah sistem dimana terjadi saling mempengaruhi antara orang dalam kelompok yang bekerjasama untuk sebuah tujuan tertentu. Timbulnya sebuah organisasi bisa dipengaruhi oleh beberapa hal antara lain, karena adanya beberapa 
orang, kerja sama, dan tujuan. Hal-hal tersebutlah yang saling terkait satu sama lain sehingga terjadi saling ketergantungan, saling membutuhkan satu sama lain dan tidak bisa lepas dan berdiri sendiri tanpa adanya faktor lain yang mendukung. Keberlangsungan sebuah organisasi tidak terlepas dari peran manajemen untuk mengatur seluruh kegiatan yang telah direncanakan dengan tepat. Organisasi apapun namanya dan jenisnya senantiasa membutuhkan manajemen. Suatu organisasi akan berjalan dengan baik apabila di kelola (manage) dengan baik pula, ini disebabkan karena manajemen dan organisasi adalah satu kesatuan yang saling melengkapi. Seperti yang dikemukakan oleh Hasibuan (2001) bahwa dalam suatu organisasi atau perusahaan, organisasi merupakan alat atau wadah, tempat untuk mengatur $6 \mathrm{M}$ (men,money, methodes, materials, machines, and market) dan semua aktivitas proses manajemen dalam mencapai tujuannya. Tegasnya pengaturan hanya dapat dilakukan didalam suatu organisasi (wadah/tempat). Sebab dalam wadah inilah tempat kerja sama, proses manajemen, pembagian kerja, koordinasi, dan integrasi dilakukan untuk mencapai tujuan yang ingin dicapai. ${ }^{1}$

Manajemen merupakan salah satu cabang dari ilmu ekonomi yang memegang peranan penting dalam keberhasilan pengelolaan suatu organisasi maupun perusahaan. Penerapan manajemen pada perusahaan dapat meningkatkan efektifitas dan efisiensi sumberdaya-sumberdaya perusahaan/organisasi sehingga mencapai hasil yang maksimal. Dalam prakteknya manajemen berperan langsung untuk mencapai suatu tujuan bersama. Dengan kata lain bahwa manajemen ada untuk mengatur semua yang dilakukan ataupun yang akan dilakukan dengan baik, tepat, rapih, dan terarah. Sebagaimana yang telah diungkapkan oleh Andrew F.Skila dalam Hasibuan bahwa management in general refers to planning, organizing, controlling, staffing, leadering, motivating, communicating, and decision making activities performed by any organization in order to coordinate the varied resources of the enterprise so as to bring an efficient creation of some product or service. $^{2}$

Artinya bahwa manajemen pada umumnya dikaitkan dengan aktivitasaktivitas perencanaan, pengorganisasian, pengendalian, penempatan, pengarahan, pemotivasian, komunikasi, dan pengambilan keputusan yang dilakukan oleh setiap organisasi dengan tujuan untuk mengkoordinasikan berbagai sumberdaya yang dimiliki oleh perusahaan sehingga akan dihasilkan suatu produk atau jasa secara efisien.

Disisi lain penyebaran konsep-konsep manajemen di berbagai negara dipengaruhi oleh budaya yang berkembang di masing-masing negara yang disebut sebagai budaya nasional. Budaya nasional memberikan bentuk dan pengaruh terhadap semua proses-proses yang berkembang didalamnya tak terkecuali dalam manajemen. Budaya nasional merupakan sekumpulan nilai, sikap dan perilaku, termasuk didalamnya yang berhubungan dengan pekerjaan dan organisasi. Budaya nasional inilah yang terbawa dalam dunia

\footnotetext{
${ }^{1}$ Malayu hasibuan, manajemen, dasar, pengertian dan masalah, edisi revisi, Jakarta, Bumi Aksara, 2001, hal.1

2 Malayu, Ibid, h. 2
}

PALITA: Journal of Social-Religion Research 
kerja, sebagai bagian dari kumpulan budaya pekerja yang akhirnya melahirkan budaya kerja. Pekerjaan yang berhubungan dengan nilai dan sikap, seperti jarak kekuasaan, toleransi untuk perbedaan, kejujuran, mencapai tujuan kelompok atau individu, etika dalam bekerja, dan semangat enterpreneur telah diperdebatkan untuk menjadi identitas budaya nasional. Lebih dari itu masyarakat dalam jumlah besar memiliki harapan yang pasti dari organisasi dan menggunakan pengaruhnya terhadap organisasi, melalui berbagai bidang formal maupun nonformal. Institusi politik, sosial dan ekonomi, seperti struktur ekonomi, serikat perdagangan, sistem pendidikan, dan tekanan kelompok, semuanya dapat digunakan sebagai pengaruh dalam organisasi. Dari beberapa hal yang dapat mempengaruhi masyarakat, agama adalah merupakan salah satu hal yang memberikan pengaruh yang cukup besar terhadap perkembangan dalam masyarakat, terutama yang menyangkut persoalan budaya dan nilai-nilai sosial didalamnya.

Pengaruh dari nilai-nilai yang ada di masyarakat merupakan keyakinan-keyakinan dan nilai-nilai yang dominan dari kondisi eksternal masyarakat. Nilai-nilai yang menjadi kebiasaan dari masyarakat itu diantaranya kebebasan individu, kolektivisme, kesopansantunan, keberhasilan, dan lain sebagainya. Hal ini memberikan warna terhadap budaya nasional satu bangsa, yang pada akhirnya memasuki aspek-aspek sosial dalam masyarakat. Dimana masyarakat Indonesia pada umumnya dikenal sebagai masyarakat yang beragam. Keberagaman dalam masyarakat Indonesia bisa ditinjau dari segi adat sampai kepada segi agama. Olehnya itu segala bentuk perbuatan dan tindakan harus mencerminkan nilai-nilai agama.

Agama Islami merupakan agama yang dipeluk oleh sebagian besar masyarakat di Indonesia dan dianggap sebagai agama mayoritas. Sebagai sebuah agama, Islami memberikan corak kepada setiap aspek kehidupan pemeluknya. Dimulai dari segi ibadah, politik, sampai kepada sosial dan ekonomi meskipun Indonesia tidak menggunakan agama sebagai dasar negara. Konsep-konsep ajaran agama ini dijalankan secara individual oleh pemeluknya. Masyarakat muslim percaya apabila keselamatan dan keberuntungan akan dicapai maka seharusnya kaum muslim mengamalkan dan menerapkan ajaran agama dalam segala aspek kehidupannya. Dengan kata lain bahwa ketika kita ingin mencapai tingkat keunggulan itu harus dimulai dengan menerapkan nilai-nilai agama didalam segala aspek kehidupan kita, apakah itu yang berhubungan langsung dengan Tuhan Allah SWT maupun dengan sesama makhluk. Termasuk dalam hal konsep manajemen, sebagaimana yang akan dibahas dalam penelitian ini.

Dalam perkembangannya, walaupun manajemen ditemukan oleh dunia barat, tetapi seiring dengan penyebaran dunia industri, manajemen dikenal dan diterapkan oleh hampir seluruh perusahaan/organisasi di seluruh dunia. Sebagai ilmu, manajemen bukanlah sesuatu yang bebas nilai. Manajemen sebagai produk peradaban manusia bukanlah sains yang bebas nilai (value free science). ${ }^{2}$ Manajemen yang dikembangkan oleh para ahli dari barat

\footnotetext{
${ }^{3}$ Larasati Oktina, Drs. Fuad Mas'ud, Praktek Penerapan Manajamen berbasis Islami pada Perusahaan,jurnal ekonomi manajemen h. 3
} 
seperti Amerika Serikat,sudah tentu dilandasi oleh pandangan / pemikiran dunia barat, dan sudah pasti mengandung nilai-nilai yang diyakini dan dianut oleh para ahli yang mengembangkannya. Sebagai salah satu contoh bahwa didalam peradaban barat, Eropa dan Amerika, ilmu/sains dipisahkan dari Agama. Hal ini merupakan warisan pertentangan antara kekristenan yang dilembagakan dengan ilmu manajemen, olehnya itu penelitian ini akan membahas mengenai seberapa besar nilai-nilai agama Islami berperan dalam penerapan ilmu manajemen pada organisasi/perusahaan. Konsep manajemen difokuskan kepada manajemen sumberdaya manusia.

Manajemen sumberdaya manusia (MSDM) bukanlah sesuatu yang baru di lingkungan suatu organisasi, khususnya di bidang bisnis yang dikenal dengan sebutan perusahaan. Usaha manusia untuk bekerjasama secara sistematik dalam arti sengaja, berencana dan terarah pada suatu/beberapa tujuan, yang disebut organisasi, sulit ditelusuri sejak kapan mulai dilakukan. Bersamaan dengan kecenderungan manusia untuk bekerjasama didalam organisasi itu, telah berlangsung juga perilaku manusia untuk memanfaatkan atau mendayagunakan manusia dalam rangka mencapai suatu tujuan. ${ }^{4}$ Disinilah peran Manajer dibutuhkan dalam keberlangsungan penerapan manajemen, khususnya manajemen sumberdaya manusia. Seperti yang diungkapkan oleh Nawawi bahwa manajemen sumberdaya manusia adalah proses mendayagunakan manusia sebagai tenaga kerja secara manusiawi, agar potensi fisik dan psikis yang dimilikinya berfungsi secara maksimal bagi pencapaian tujuan organisasi/perusahaan. ${ }^{5}$

Begitupun dengan keberhasilan penerapan manajemen dalam organisasi akan tergantung dari peran-peran yang ada didalamnya, seperti manajer, karyawan, dan variabel - variabel lain yang menunjang. Namun dengan adanya perbedaan - perbedaan peran tersebut akan mempengaruhi penerapan manajemen yang berbeda pula, terutama peran seorang manajer atau pimpinan yang berperan langsung terhadap proses manajemen. Walaupun mungkin diterapkan secara berbeda oleh manajer-manajer yang berbeda pula, dalam hal ini tergantung pada variabel-variabel seperti tipe organisasi, kebudayaan dan tipe karyawan. Disinilah peran manajer dibutuhkan dalam keberlangsungan penerapan manajemen, khususnya manajemen sumberdaya manusia karena sumberdaya yang paling penting dari suatu organisasi adalah sumberdaya manusia.

Sebagai aspek terpenting dalam berlangsungnya aktivitas usaha sebuah organisasi Manajemen SDM memiliki fungsi-fungsi yang utama, dijelaskan oleh Flippo dalam Handoko bahwa manajemen sumberdaya manusia adalah suatu proses perencanaan, pengorganisasian, pengarahan, dan pengawasan kegiatan-kegiatan pengadaan, pengembangan, pemberian kompensasi, pengintegrasian, pemeliharaan, dan pelepasan sumberdaya manusia agar tercapai berbagai tujuan hidup individu, organisasi dan masyarakat. ${ }^{6}$

${ }^{4}$ Hadari Nawawi, Manajemen Sumberdaya Manusia Untuk Bisnis Yang Kompetitif, Yogyakarta, Gadjahmada University Press, 2000, h. 1

${ }^{5}$ Hadari Nawawi, Ibid, h. 42

${ }^{6}$ Hani Handoko, Manajemen Personalia dan Sumberdaya Manusia, Yogyakarta, BPFE, 1994, h.3 
Perkembangan dan penerapan manajemen khususnya manajemen sumberdaya manusia dalam suatu organisasi tidak lepas dari budaya yang berkembang di wilayah dimana organisasi tersebut berada. Sebagai sebuah kenyataan bahwa sejarah, agama, dan kebudayaan dapat saling mempengaruhi karena ketiganya mengandung nilai dan simbol. Secara tidak langsung, keberadaan agama dalam masyarakat akan mempengaruhi perkembangan budaya dan nilai-nilai sosial bahkan ekonomi, sehingga pola pikir baik individu ataupun masyarakat sehari-hari akan berdasarkan pada aturan agama.

Al Qur'an menegaskan kepada setiap muslim untuk senantiasa terkait dengan aturan-aturan Allah SWT dalam setiap aspek kehidupan yang dijalankannya, termasuk dalam hal konsep manajemen. Penelitian ini akan menginvestigasi seberapa besar pengaruh/peran nilai-nilai yang ada dalam agama Islami dalam penerapan konsep manajemen khususnya Manajemen SDM pada suatu organisasi/perusahaan. Manajamen SDM digunakan sebagai salah satu kunci utama dalam pencapaian tujuan, baik individu maupun organisasi. Penerapan fungsi-fungsi manajemen terutama Manajemen SDM bertujuan sebagai pengefektifan manusia-manusia yang ada dalam melakukan suatu aktivitas tertentu yang mengarah pada tujuan utama yaitu keuntungan yang maksimal

Aktivitas dan perilaku ekonomi tidak terlepas dari karakteristik manusianya, seperti dalam hal sistem perbankan yang mempengaruhi perekonomian masyarakat. Masyarakat yang mayoritas beragama Islami juga memerlukan adanya sistem perbankan yang menggunakan prinsip sesuai syariah. Perkembangan perbankan syariah yang tumbuh cukup pesat dalam beberapa tahun terakhir menunjukkan minat masyarakat mengenai ekonomi syariah semakin bertambah. Dalam perkembangan yang sangat menggembirakan ini disadari oleh banyak pihak bahwa kebutuhan kepada SDM berbasis Syariah merupakan suatu keniscayaan. Kebutuhan adanya SDM yang handal sebagai pondasi berkembangnya ekonomi syariah dalam lembaga keuangan dan perbankan syariah merupakan tantangan yang sekaligus dapat dijadikan sebagai peluang. Sebagaimana dimaklumi melalui berbagai media dan informasi, Bank Indonesia memprediksi industri perbankan syariah membutuhkan SDM sekitar 50 ribu sampai 60 ribu hingga tahun 2011. Hal tersebut ditetapkan nampaknya, di samping semakin bertambahnya "pemainpemain baru" lembaga keuangan dan perbankan syariah, sekaligus juga untuk mendorong berkembangnya aset perbankan syariah di Indonesia agar tumbuh sebagaimana yang diharapkan.Kegiatan usaha perbankan syariah pada dasarnya merupakan perluasan jasa perbankan bagi masyarakat yang membutuhkan dan menghendaki pembayaran imbalan yang tidak didasarkan pada sistem bunga, melainkan atas dasar prinsip syariah sebagaiman yang digariskan oleh syariah (hukum) Islami.

Keberadaan sistem perbankan syariah dapat memenuhi kebutuhan sabagian masyarakat yang tidak bersedia memanfaatkan jasa-jasa bank konvensional karena prinsip keyakinan atau kepercayaan. Pada dasarnya, produk perbankan syariah bersifat universal, tidak hanya dikhususkan untuk suatu kelompok masyarakat tertentu, meskipun prinsip operasi bank syariah 
ini didasarkan pada syariah Islami, yaitu Al Qur'an dan Al Hadits. Keberadaan Sumber Daya Manusia (SDM), baik pada aspek kualitas maupun kuantitas memang sangat menentukan kinerja, produktifitas dan keberhasilan suatu institusi. Bagi perbankan syariah sebagai institusi bisnis yang berbasis nilainilai dan prinsip-prinsip syariah, kualifikasi dan kualitas SDM jelas lebih dituntut adanya keterpaduan antara " knowledge, skill dan ability" (KSA) dengan komitmen moral dan integritas pribadi. Penekanan pada aspek moralitas, yang dewasa ini diyakini sebagai "key success factor" seperti yang diungkapkan oleh Hermawan Kartajaya dan Syakir Sula yang menjelaskan bahwa dalam pengelolaan bisnis, lembaga keuangan dan perbankan syariah, yaitu "shiddiq (benar dan jujur), amanah (terpercaya, kredibel), tabligh (komunikatif) dan fathanah (cerdas) " sama pentingnya dengan pengetahuan, kemampuan dan keterampilan. SDM Syariah yang bekerja di lembaga-lembaga keuangan dan perbankan syariah dewasa ini dianggap sebahagian besar hanya SDM "dadakan" dan "karbitan" memenuhi kebutuhan yang mendesak, yang memperoleh ilmu kesyariahannya dalam waktu yang sangat terbatas. ${ }^{7}$

Dari alasan-alasan tersebut yang telah diuraikan di atas peneliti bermaksud menganalisis mengenai implikasi konsep Manajemen Sumberdaya Manusia berbasis nilai-nilai Islami pada perusahaan perbankan syariah dalam hal ini Bank Muamalat Palopo. Rumusan masalah dalam penelitian ini adalah :

1. Bagaimana implikasi MSDM pada proses perekrutan, seleksi, kontrak kerja, pendidikan, pengembangan dan kompensasi apakah sudah sesuai dengan nilai-nilai Islami

2. Bagaimana pemahaman karyawan mengenai manajemen sumberdaya manusia yang berbasis nilai-nilai Islami

3. Bagaimana bentuk-bentuk implikasi manajemen sumberdaya manusia berbasis nilai-nilai Islami pada Bank Muamalat Palopo

Sedangkan kegunaan dari penelitian ini adalah:

1. Kegunaan teoritis, diharapkan hasil penelitian ini dapat menjadi tambahan bagi ilmu pengetahuan yang berhubungan dengan bidang manajemen khususnya manajemen sumberdaya manusia lebih khusus lagi yang bernilai Islami.

2. Kegunaan praktisi, hasil penelitian ini diharapkan dapat menjadi masukan bagi pihak yang terkait dalam mengatur sumberdaya manusia yang dilandasi oleh nilai-nilai Islami, atau dapat menjadi bahan acuan bagi penelitian selanjutnya.

\section{METODE}

Untuk menghasilkan penelitian yang akurat, penulis menggunakan beberapa pendekatan, yaitu:

1. Pendekatan normatif, yakni pendekatan yang berpegang teguh kepada norma atau kaidah-kaidah dan nilai-nilai yang berlaku yang sesuai dengan nilai-nilai Islami

\footnotetext{
${ }^{7}$ Hermawan Kartajaya,Muhammad Syakir Sula, 2006, Syariah Marketing, Mizan Media Utama, Bandung. h.120
} 
2. Pendekatan psikologis yaitu suatu bentuk pemecahan masalah dengan melihat gejala-gejala kejiwaan dari suatu tingkah laku.

3. Pendekatan sosiologis yaitu pendekatan yang digunakan untuk mengetahui apakah konsep yang ditawarkan sesuai dengan kondisi lingkungan perusahaan baik internal maupun eksternal.

Adapun jenis penelitian yang digunakan dalam penelitian ini adalah penelitian kualitatif yaitu penelitian yang menghasilkan prosedur analisis yang tidak menggunakan prosedur analisis statistik atau dengan menggunakan cara kuantifikasi.

Lokasi penelitian ini berada dalam wilayah kota Palopo dengan alasan bahwa Bank Muamalat sebagai Bank Syariah pertama di Indonesia yang murni syariah telah membuka kantor cabang di Palopo, sehingga dapat memudahkan peneliti untuk melakukan penelitian.

Populasi dalam penelitian adalah seluruh jajaran dari Bank Muamalat cab. Palopo, mulai dari bawah sampai kepada level pimpinan. Sampel adalah sebagian dari populasi yang ditentukan sebelumnya. Untuk penentuan sampel pada Bank Muamalat digunakan tekhnik purfpsive sampling yaitu memilih pihak-pihak yang dianggap berkompetensi dalam menyelesaikan permasalahan yang ada. Sehubungan dengan hal tersebut di atas maka dalam peneetuan sampel dipilih bagian HRD yang pada Bank Muamalat Palopo Bagian HRD di gabung dalam Bagian Operasional.

Sumber data yang digunakan dalam penelitian ini ada dua, yaitu:

1. Data primer, merupakan data yang diperoleh secara langsung dari responden melalui wawancara dan observasi langsung ke lapangan. Responden adalah orang yang dikategorikan sebagai subyek dalam penelitian yang merespon pertanyaan-pertanyaan peneliti.

2. Data sekunder merupakan jenis data yang diperoleh secara tidak langsung melalui publikasi dan informasi yang dikeluarkan diberbagai perusahaan, misalnya data yang diperoleh dari dokumen-dokumen yang umumnya berupa bukti catatan/laporan historis yang telah tersusun dalam arsip menyangkut profil Bank Muamalat Cab. Palopo.

Untuk memperoleh data dalam penelitian ini teknik pengumpulan data menggunakan instrumen pertanyaan yaitu memberikan pertanyaan kepada bagian HRD/Operasional. Dalam lembaran pertanyaan itu tidak disediakan pilihan jawaban tetapi lebih kepada pihak Bank Muamalat memberikan jawaban baik lisan maupun tertulis.

Pengumpulan data dilakukan dengan beberapa cara, yaitu:

1. Observasi yaitu pengamatan langsung di lapangan terhadap implikasi MSDM pada beberapa aspek MSDM antara lain, perekrutan, seleksi, pengembangan, pemberian kompensasi, penilaian kinerja.

2. Interview/wawancara adalah sebuah dialog yang dilakukan oleh pewawancara untuk memperoleh informasi dari terwawancara. Teknik wawancara ini digunakan untuk mengetahui sejauh mana pihak perusahaan menerapkan MSDM yang berbasis nilai-nilai Islami

3. Dokumentasi yaitu dokumen-dokumen berupa aturan-aturan yang dibuat oleh perusaahaan berkaitan dengan MSDM 
Metode analisis yang digunakan dalam penelitian ini adalah analisis deskriptif kualitatif. Untuk kepentingan tersebut, penulis hanya menyajikan data lapangan sebagaimana adanya, lalu selalu menggunakan analisis deskriptif.

Dalam mengelolah dan menganalisis data dalam penelitian ini penulis menggunakan metode kualitatif. Metode kualitatif adalah metode yang digunakan untuk mengkategorikan data menurut gambaran kualitas objek yang diteliti, sehingga data yang diperoleh dibuatkan kategori-kategori sesuai dengan kualitas data yag diperoleh. Metode kualitatif tersebut menyangkut:

1. Metode induktif, yaitu suatu proses berpikir yang bertolak dari suatu atau sejumlah data spesifik untuk menurunkan suatu kesimpulan dengan cara generalisasi atau analogi, atau hubungan kausal. Metode ini dipergunakan untuk mengkaji beberapa hal yang dijadikan objek penelitian. Kemudian dari hal yang dianalisis dapat di tarik kesimpulan, kesimpulan-kesimpulan dari beberapa hal tadi kemudian dijadikan sebagai suatu kesimpulan makro dari penelitian ini.

2. Metode deduktif, yaitu suatu proses berpikir yang bertitik tolak dari suatu proposisi yang telah ada, untuk memperoleh suatu proposal baru sebagai kesimpulan. Metode ini dipakai dalam rangka menganalisa beberapa rumusan cara berpikir yang telah ditetapkan. Kemudian melihat penerapan-penerapannya pada kasus-kasus yang terjadi pada objek penelitian.

Kedua metode ini digunakan untuk menganalisis mengenai Implikasi Manajemen Sumber Daya Manusa yang berbasis nilai-nilai Islam pada Bank Muamalat cab. Palopo. Dengan menggunakan beberapa methode di atas penulis berharap dapat membuat suatu kesimpulan yang komprehensif.

\section{IMPLIKASI MANAJEMEN SDM BERBASIS NILAI-NILAI ISLAMI PADA BANK MUAMALAT PALOPO}

Sumber daya manusia merupakan jantung operasional bagi perusahaan. Menyadari hal tersebut, Bank Muamalat menempatkan Sumber Daya manusia atau sumberdaya Insani sebagai suatu modal penting dalam mencapai tujuan Perseroan. Untuk meningkatkan profesionalisme dan kinerja usaha secara berkelanjutan, telah dicanangkan program pengembangan kualitas sumber daya manusia profesional secara konsisten melalui sistem pengelolaan sumber daya manusia secara terpadu. Untuk itu pemakaian Human Capital Information System (HCIS) atau yang dikenal sebagai Muamalat Human Power (MHP) menjadi penting karena didalam aplikasi tersebut terdapat fungsi administrasi kepegawaian, online training dan media sosialisasi terkait peraturan baik internal maupun eksternal yang dapat dilakukan secara langsung di komputer kerja karyawan masing-masing. ${ }^{3}$

Pemenuhan kebutuhan akan Sumber Daya Insani merupakan salah satu fokus utama manajemen Bank Muamalat seiring pesatnya pertumbuhan

3 Data Laporan Bank Muamalat, h. 314 
volume bisnis dalam beberapa tahun terakhir ini. 2 Setelah melakukan serangkaian penelitian dan pengkajian yang sistematis terhadap penerapan manajemen sumberdaya manusia yang berbasis nilai-nilai Islami atau lebih dikenal dengan manajemen sumberdaya manusia syariah yang diterapkan pada Bank Muamalat Palopo sebagai salah satu Bank syariah dan sebagai Bank pelopor munculnya perbankan syariah di Indonesia maka pada akhirnya diperoleh data-data dari hasil penelitian yang lengkap, valid dan akurat. Berdasarkan data-data dari hasil penelitian yang diperoleh dari wawancara, dan lain-lain, maka dari hasil perolehan tersebut akan diuraikan secara jelas pada bab ini, sebagai berikut:

\section{A. Implikasi MSDM terhadap budaya perusahaan}

Keberhasilan suatu perusahaan sangat dipengaruhi oleh kemampuan sumber daya manusianya, keunggulan produk atau jasa yang dijual, jaringan, dan teknologi yang unggul guna mendukung operational excellence. Komponen tersebut bukanlah penentu yang menjadi kunci keberhasilan suatu bisnis. Faktor pendorong yang sesungguhnya terletak pada kekuatan visi dan misi serta nilai-nilai yang menjadi sumber inspirasi dan energi budaya kerja perusahaan.

Hal ini dibuktikan oleh Bank Muamalat yang memiliki visi menjadi bank syariah utama di Indonesia, dominan di pasar spritual, dikagumi di pasar rasional dengan misi menjadi role model lembaga keuangan syariah dunia yang penekanannya pada semangat kewirausahaan, keunggulan manajemen dan orientasi investasi yang inovatif untuk memaksimumkan nilai kepada stakeholders. ${ }^{3}$

Pencapaian visi dan misi tersebut sangat didukung oleh nilai-nilai yang tertanam dan ditumbuhkembangkan oleh individual serta positioning Perseroan sebagai lembaga keuangan syariah, sehingga harus digerakkan dengan sistem, akhlak, dan akidah sesuai prinsip syariah. Bank Muamalat menjunjung praktik kejujuran sejak awal rekrutmen, serta larangan menerima imbalan dalam bentuk apapun dari para nasabah dan mitra kerja. Selain itu Bank Muamalat juga sangat tegas dalam menyikapi risiko reputasi yang ditimbulkan karyawan akibat perilaku yang tidak sesuai dengan tatanan budaya, etika, dan hukum.

Penilaian kinerja terhadap karyawan mengacu kepada scoreboard berdasarkan aspek-aspek finansial dan kepatuhan. Pengangkatan staf dan pejabat yang akan memangku jabatan harus melalui prosesi sumpah jabatan secara lisan dan tertulis tentang pernyataan tujuh perilaku sebagai pedoman perilaku (code of conduct) yang harus dipertanggungjawabkan dengan janji untuk:

1. Mentaati peraturan perundang-undangan dan ketentuanperusahaan

2. Memegang teguh rahasia bank dan perusahaan

3. Tidak menerima hadiah dalam bentuk apapun terkait

4. Tugas dan jabatan

\footnotetext{
2 Data Laporan Bank Muamalat, h.100

3 ibid Data Laporan Bank Muamalat, h.23
} 
5. Menjunjung kehormatan perusahaan dan karyawan

6. Bekerja sesuai dengan prinsip syariah

7. Berpegang teguh pada akhlak Islam dalam menjalani kehidupan sehari-hari

8. Bertanggung jawab terhadap kesalahan dan pelanggaran yang dilakukan Bank Muamalat, senantiasa menjunjung tinggi etika bisnis yangberorientasi kepada kemaslahatan, khususnya kepuasan nasabah dan segenap pemangku kepentingan. ${ }^{3}$

Melihat kebiasaan kebiasan yang berlaku pada Bank Muamalat akan lebih memperjelas bahwa penerapan manajemen sumberdaya manusia/insani yang bernilai Islami memang telah menjadi tekad dan tujuan dari Bank Muamalat. Aturan, kode etik, janji yang harus dipatuhi oleh karyawan yang akan memangku suatu jabatan lebih mempertegas bahwa budaya perusahaan merupakan suatu bagian dari manajemen sumberdaya insani.

Pada Bank Muamalat Palopo budaya atau kebiasaan yang diterapkan oleh perusahaan adalah setiap hari sebelum memulai pekerjaan dilakukan breaving untuk membicarakan hasil dan kendala yang terjadi pada hari kemarin, sehingga segala permasalahan yang kadang timbul dapat diatasi dengan cepat. Kebiasaan breaving adalah merupakan anjuran dalam agama yaitu untuk selalu bermusyawarah apabila terjadi perbedaan-perbedaan pendapat atas sesuatu untuk melahirkan kebaikan dan kebenaran didalamnya.. Disamping itu ada beberapa kegiatan yang dilakukan dan menjadi kegiatan rutin dalam setiap minggunya, seperti silaturrahim sesama karyawan dan silaturrahim antara karyawan dan keluarga karyawan baik dalam bentuk pengajian maupun dalam bentuk family gatering, family day yang dilakukan pada setiap awal tahun. Kebiasaan-kebiasaan ini sudah menjadi budaya yang diterapkan di Bank Muamalat Palopo.

\section{B. Implikasi MSDM terhadap proses perekrutan dan seleksi}

Transformasi Sumber Daya Insani (SDI) Bank Muamalat dalam aspek kuantitas maupun kualitas terus berlangsung sebagai bagian dari proses transformasi Bank Muamalat sejak tahun 2009. Pada tahun 2013, Bank Muamalat memberikan prioritas pada program zero gap manpower need, untuk terus mengejar pemenuhan kebutuhan SDI dari sisi kuantitas. sejalan dengan pesatnya Seiring dengan pertumbuhan bisnis dari tahun ke tahun jumlah SDI Bank Muamalat pertumbuhan usaha di beberapa tahun sebelumnya, serta dari sisi kualitas melakukan penyelarasan kompetensikompetensi yang dibutuhkan terutama guna menunjang implementasi strategi line of business ke depan. Keseluruhan upaya pengembangan tersebut dilakukan secara konsisten untuk membentuk Sumber Daya Insani Bank Muamalat yang Islami, Modern dan Profesional. juga terus bertambah dari 2.732 karyawan pada tahun 2010, 3.556 karyawan di tahun 2011, 4.933 karyawan di tahun 2012, dan pada akhir tahun 2013 jumlah tersebut telah mencapai sebanyak 6.020 karyawan. $^{2}$

\footnotetext{
3 ibid laporan Tahunan Bank Muamalat, h. 24

2 Ibid. Data Laporan Bank Muamalat, h.101
} 
Pada tahun 2013, Bank Muamalat merekrut 1.487 karyawan baru untuk mengisi kekosongan atau kekurangan tenaga kerja di beberapa fungsi yang telah terjadi sejak beberapa tahun terakhir, serta untuk memenuhi kebutuhan penambahan karyawan yang diantisipasi sesuai pengembangan bisnis yang dilakukan. Tingkat turnover karyawan pada tahun 2013 sementara itu adalah sebesar 9,23\%, dibandingkan 4,7\% ditahun 2012. Proses rekrutmen dilakukan melalui berbagai jalur atau pendekatan, termasuk proses perekrutan dan seleksi online berbasis web, direct sourcing ke perguruanperguruan tinggi yang accredited, keikutsertaan pada job fairs, iklan di media serta personal referral. Salah satu perkembangan yang menarik adalah kenyataan bahwa proses pencarian tenaga kerja pada tahun 2013 telah menjadi lebih mudah dibandingkan dengan tahun-tahun sebelumnya. Kondisi ini seiring dengan semakin meningkatnya citra brand Bank Muamalat di masyarakat, termasuk di pasar tenaga kerja, sehingga Bank Muamalat semakin diminati oleh para lulusan S1 perguruan perguruan tinggi terkemuka yang berminat berkarir di dunia perbankan. ${ }^{3}$

Pada kegiatan rekrutmen dan seleksi berkaitan dengan implikasi MSDM bernilai Islami yang diterapkan oleh Bank Muamalat adalah jelas bahwa perekrutan dan seleksi yang dilakukan oleh Bank Muamalat selama ini adalah berdasarkan kekosongan atau kekurangan tenaga kerja di beberapa fungsi serta untuk memenuhi kebutuhan penambahan karyawan yang diantisipasi sesuai pengembangan bisnis yang dilakukan. Proses rekrutmen dilakukan melalui berbagai jalur atau pendekatan, termasuk proses perekrutan dan seleksi online berbasis web, direct sourcing ke perguruan-perguruan tinggi yang accredited, keikutsertaan pada job fairs, iklan di media serta personal referral.

Untuk Bank Muamalat Palopo proses rekrutmen dan seleksi dilakukan dengan membuka lowongan kerja dengan persetujuan kantor cabang Makassar, kemudian seluruh berkas akan diseleksi pada kantor Bank Muamalat Palopo, adapun proses perekrutannya persyaratan yang dibutuhkan adalah persyaratan yang umum diberlakukan disetiap perusahaan, sedangkan untuk persyaratan seleksi secara khusus adalah yang menguasai masalah perbankan khususnya perbankan syariah, dan mampu membaca Al Qur'an. Hasil seleksi berkas selanjutnya akan dilanjutkan ke Bank Muamalat Makassar untuk diseleksi ulang, kemudian hasil dari seleksi itu akan dkembalikan ke kantor penyelenggara, dan penempatan akan ditetapkan oleh pihak Bank Muamalat Makassar. Dari penjelasan tersebut sehingga dalam pelaksanaan perekrutan dan seleksi pada Bank Muamalat dapat dikatakan sesuai dengan syariah atau bernilai Islami, ini tercantum dalam budaya perusahaan yang dianut oleh Bank muamalat indonesia yakni berpegang teguh pada akhlak Islam dalam menjalani kehidupan sehari-hari, termasuk pada proses rekrutmen dan seleksi karyawan.

\section{Implikasi MSDM terhadap pengembangan potensi karyawan Bank Muamalat}

${ }^{3}$ Ibid. Data Laporan Bank Muamalat, h.101 
Bank Muamalat terus melakukan upaya peningkatan produktivitas karyawan melalui berbagai program pelatihan dan pendidikan, yang dirancang untuk mendukung implementasi strategi line of business melalui peningkatan kompetensi-kompetensi yang berdampak langsung pada peningkatan pendapatan ataupun pencapaian sasaran-sasaran bisnis lainnya. Selain itu, pemberian pelatihan dan pendidikan juga merupakan bagian dari imbalan atas prestasi kerja karyawan, untuk memenuhi persyaratan kompetensi jabatan dalam rangka promosi jabatan atau kelanjutan jenjang karir karyawan.

Muamalat Human Power merupakan pola pendekatan dalam membangun suatu sistem manajemen sumber daya insani yang unggul dengan kompetensi sebagai titik sentralnya. Hal ini dimaksudkan agar perusahaan dapat meningkatkan efektivitas dan konsisten dalam menerapkan sistem promosi, kompensasi, penilaian kinerja, pendidikan dan pelatihan, perencanaan karir, manajemen kinerja, maupun perencanaan strategis di bidang sumber daya manusia ke titik yang paling optimum. Model Kompetensi Bank Muamalat meliputi Rumpun Jabatan, Jenis/Tipe Kompetensi serta proses pemetaan Profil Kompetensi dilakukan pembaharuan secara berkesinambungan agar tetap sejalan dengan arah strategi bisnis perusahaan.

Adapun urgensi dari penggunaan Model Kompetensi adalah untuk proses rekrutmen pegawai baru, proses rotasi,mutasi dan promosi pegawai, serta sebagai salah satu indikator dalam pencapaian kinerja pegawai dalam perusahaan. Dibawah ini adalah gambar dari aplikasi Muamalat Human Power.

Secara garis besar, program-program pengembangan kompetensi karyawan didasarkan pada 4 matrix pengembangan karyawan, yaitu (i) Initial Development Program seperti program pengenalan awal Muamalat Ways; (ii) Regular Development Program seperti Front Liner Academy dan Consumer Academy Program; (iii) Strategic Development Program seperti Muamalat Officer Development Program (MODP) dan Branch Manager Academy, serta (iv) Strategy Related Program seperti high-level seminar/lokakarya.

Bank Muamalat memberikan kesempatan belajar bagi pegawainya, baik pegawai yang sudah lama bekerja di Bank Muamalat maupun yang baru bergabung. Hal ini untuk mendukung pekerjaan mereka, menjadi yang terbaik dalam pekerjaannya serta terus mengembangkan karirnya. Kategori training ini dibagi menjadi 5 (lima) program, yaitu:

1) Core Banking Program yaitu training yang wajib diikuti oleh seluruh karyawan disemua level.

2) Leadership \& Management Program yaitu training soft skill yang berkaitan dengan peningkatan kemampuan leadership dan manajerial karyawan.

3) Bussiness Program yaitu training yang berkaitan dengan kegiatan bisnis perusahaan, khususnya pembiayaan.

4) Operation Program yaitu training yang berkaitan dengan bidang operasional perusahaan.

5) Supporting Program yaitu training yang berkaitan dengan fungsi supporting dalam rangka memperlancar kegiatan bisnis di cabang yang meliputi bagian atau divisi. 
Dari ke 5 (lima) kategori tersebut dibagi ke dalam 2 (dua) jenis training, yaitu sebagai berikut:

1) Training internal yaitu training yang dilakukan secara inhouse oleh Muamalat Institute maupun diselenggarakan sendiri oleh Bank Muamalat yang dikoordinir langsung oleh Human Capital.

- Classical training yaitu kegiatan training yang dilakukan secara tatap muka langsung dalam suatu ruangan / kelas.

- E-Learning yaitu kegiatan training melalui media elektronik (internet dan intranet). Untuk beberapa program E-learning ini sedang dikembangkan oleh Human Capital dan akan diimplementasikan dengan menggunakan media Muamalat Human Power (MHP).

2) Training Eksternal yaitu training yang penyelenggaranya bukan dari Muamalat Institute maupun yang dikoordinir langsung oleh Human Capital. Training eksternal ini biasanya dilakukan secara individu (tidak masal) sesuai dengan kebutuhan masing-masing karyawan dalam meningkatkan kompetensi.

Pelatihan yang telah dilakukan oleh Bank Muamalat, diantaranya sebagai berikut:

1) Pelatihan Aspek Hukum Fraud;

2) Pelatihan Investigasi Berbasis Fraud

3) Front Liner Academy;

4) Pelatihan Basic Sharia Banking;

5) Pelatihan Basic Sharia Financing;

6) Legal Training;

7) Pelatihan Negotiation Skill;

8) Pelatihan Taksasi, Legal, dan Asuransi;

9) Pelatihan Trade Finance;

10) Pelatihan LOB Palm Oil \& LOB Property;

11) Workshop IT Governance-Reflections on Risk And Value

Pesatnya pertumbuhan jumlah karyawan Bank Muamalat memberikan tantangan tersendiri terhadap upaya mempersiapkan para lulusan perguruan tinggi yang baru direkrut menjadi tenaga officer bank yang handalmelalui penyelenggaraan MODP, yang pada tahun 2013 telah dilakukan sebanyak 14 angkatan dengan total 349 partisipan. Ini merupakan peningkatan yang cukup signifikan dibandingkan 8 angkatan MODP dengan 211 peserta pada tahun sebelumnya. Selain program MODP yang bersifat generalis dengan lama pendidikan 10 bulan, Bank Muamalat juga menyelenggarakan MODP spesialis dengan durasi 4 bulan untuk fungsi-fungsi Auditor, Funding, Operations dan Consumer Financing. Pada tahun 2013, program MODP spesialis tercatat terselenggara sebanyak 7 angkatan dengan 165 peserta. 4

Salah satu perkembangan penting di tahun 2013 adalah diresmikannya fasilitas Muamalat Training Resort yang berlokasi di kawasan Gunung Geulis, Bogor, Jawa Barat. Fasilitas ini memiliki arti yang strategis mengingat bahwa dalam rangka mendukung pertumbuhan bisnis ke depan, dibutuhkan setidaknya 50 ribu jam pelatihan karyawan per tahun, atau setara dengan

${ }^{4}$ Laporan Tahunan Bank Muamalat. Ibid. h. 106 
penyelenggaraan 20 ruang kelas pelatihan sehari untuk 200 hari kerja dalam setahun. Pemusatan pelatihan di Muamalat Training Resort dengan demikian akan dapat mengatasi masalah kerumitan penjadwalan pelatihan yang selama ini dilakukan di berbagai hotel atau fasilitas sejenis yang berbeda-beda sehingga dapat lebih efisien. Selain itu, penyelenggaraan pelatihan juga sekaligus diharapkan dapat lebih efektif karena para peserta dapat berkonsentrasi mengikuti sesi-sesi pembelajaran di lingkungan yang dirancang khusus untuk belajar dan sekaligus nyaman. ${ }^{5}$ Pada Bank Muamalat Palopo proses pengembangan karyawan dilakukan dengan berbagai cara, misalnya diadakan pelatihan bagi karyawan yang berkaitan dengan perbankan syariah, kegiatan ini ditangani oleh Bank Muamalat Makassar bekerja sama dengan Manajemen Bank Muamalat Pusat. Dalam hal peningkatan kompetensi karyawan atau lebih dikenal dengan pengembangan karyawan Bank Muamalat Indonesia telah melakukan hal yang sangat positif. Jika ditinjau dari nilai Islami pengembangan atau peningkatan kompetensi karyawan adalah hal yang penting yang bertujuan untuk lebih meningkatkan kemampuan karyawan sehingga karyawan dapat lebih berkualitas. Ini sejalan dengan firman Allah SWT dalam Al Qur'an Surah Ar-ra'd ayat 11 yang artinya: Sesungguhnya Allah tidak akan mengubah nasib / keadaan suatu kaum sehingga mereka mengubah keadaan yang ada pada diri mereka. (QS. Ar-ra'd :11)

Untuk itulah pengembangan karyawan yang dilakukan oleh Bank Muamalat dalam rangka merubah atau lebih meningkatkan pengetahuan dan keterampilan dengan beberapa kegiatan adalah telah sesuai dengan apa yang dijelaskan dalam Al Qur'an, karena dengan peningkatan pengetahuan dan keterampilan bagi karyawan itu akan menjadikan karyawan bisa lebih berkembang.

\section{Implikasi terhadap Penilaian Kinerja dan Kompensasi Karyawan}

Sistem penilaian kinerja karyawan serta strategi remunerasi karyawan merupakan dua aspek yang saling terkait dan sangat penting agar karyawan dapat berkontribusi secara optimal terhadap peningkatan kinerja Bank Muamalat. sampai dengan tahun 2013, sistem penilaian kinerja karyawan dilakukan dengan 2 (dua) parameter pengukuran, yaitu pencapaian Key Performance Indicator (KPI) serta penilaian aspek hasil kerja, cara kerja dan sifat individu. ${ }^{6}$ Kedua parameter tersebut kemudian digabungkan dan menghasilkan satu nilai total.

Sejalan dengan penerapan strategi pengelolaan sumber daya manusia yang berbasis prestasi dan kompetensi, Bank Muamalat telah mulai mengembangkan konsep Sistem Pengelolaan Kinerja (Performance Management System/ PMS), dimana kinerja karyawan akan dinilai berdasarkan parameter pencapaian KPI serta penguasaan 7 (tujuh) bidang kompetensi meliputi kompetensi umum maupunkompetensi inti. Konsep PMS telah diterapkan mulai tahun 2014, dan dalam teknis pelaksanaannya akan diintegrasikan ke dalam sistem Muamalat Human Power.

\footnotetext{
5 laporan Tahunan Bank Muamalat ibid, h. 107

${ }^{6}$ laporan Tahunan Bank Muamalat ibid, h. 109
} 
Sementara itu, strategi remunerasi karyawan tetap didasarkan pada prinsip pay for performance dan dengan mengacu kepada standar yang berlaku di industri khususnya di kelompok peer banks. Paket remunerasi karyawan berupa gaji dan tunjangan juga ditinjau dari waktu ke waktu dan disesuaikan terhadap faktor kenaikan biaya hidup (inflasi) maupun peningkatan pada kemampuan finansial Bank Muamalat. Secara keseluruhan, strategi remunerasi karyawan dirancang untuk dapat memotivasi peningkatan kinerja karyawan, mempertahankan karyawan yang berkinerja tinggi, dan menjadi daya tarik bagi calon karyawan untuk bergabung dengan Bank Muamalat.

Pada Bank Muamalat Palopo penerapan penilaian kinerja dan kompensasi karyawan merupakan hal yang dapat meningkatkan motivasi bagi karyawan, hal tersebut biasa berbentuk pemberian reward atau penghargaan kepada karyawan yang mencapai target tertentu. Reward paling tertinggi yang diberikan oleh Bank Muamalat kepada karyawan yang telah mencapai target adalah dengan memberangkatkan umrah bagi karyawan, disamping rewardreward yang lain, misalnya dengan memberikan bonus berupa uang yang langsung masuk ke rekening karyawan apabila karyawan tersebut dapat mencapai target yang ditentukan. Dari keterangan tersebut dapatlah dikatakan bahwa penerapan MSDM terhadap penilaian kinerja dan pemberian kompensasi karyawan telah sesuai dengan nilai nilai Islami, sebab dalam ajaran islam telah dijelaskan dalam hadits Nabi saw yang diriwayatkan oleh Bukhari dan Muslim dalam Abu Fahmi, yang artinya :

Mereka (para budak dan pelayanmu)adalah saudaramu, Allah menempatkan mereka dibaah asuhanmu, sehingga barang siapa mempunyai saudara di bawah asuhannya maka harus diberinya makan seperti apa yang dimaknnya (sendiri); dan tidak membebankan pada mereka dengan tugas yang sangat berat, dan jika kamu membebankannya dengan tugas seperti itu, maka hendaklah membantu mereka (mengerjakannya) ${ }^{7}$

\section{E. Implikasi MSDM terhadap Hubungan Industrial}

Membahas mengenai hubungan industrial atau hubungan antara karyawan dan manajemen, terkadang bahkan sering kali ada pada suatu kondisi yang mengakibatkan para karyawan tidak merasa puas. Hal tersebut mendorong mereka untuk berkumpul dan membentuk organisasi dalam perusahaan. Di Indonesia organisasi karyawan lebih dikenal dengan sebutan serikat pekerja. Tidak dipungkiri lagi bahwasanya hubungan serikat pekerja dengan pihak manajemen sering kali tidak harmonis dan seia kekata. Kadang kala timbul gejolak yang pada akhirnya dapat merugikan eksistensi kedua belah pihak. Hal-hal yang paling sering menjadi perdebatan diantara keduanya adalah masalah penetapan upah atau gaji dan status hubungan kerja.

Pengelolaan hubungan industrial di Bank Muamalat didasarkan pada prinsip kesetaraan dan kewajaran/keadilan dalam penyelesaian masalahmasalah hubungan industrial antara manajemen Bank Muamalat dan

7 Abu Fahmi, HRD Syariah, Teori dan Implementasi, Jakarta; PT. Gramedia Pusaka Utama, 2014, h.186 
karyawan, serta niat untuk menjaga hubungan yang baik dan bermanfaat dengan seluruh karyawan ${ }^{8}$. Dalam peranannya MSDM bernilai Islami diwujudkan melalui kesepakatan antara manajemen dengan karyawan, yang diwakili oleh Serikat Pekerja Bank Muamalat, dan dituangkan dalam bentuk dokumen Perjanjian Kerja bersama (PKB) yang diperbaharui setiap 2 (dua) tahun sekali.

Berkaitan dengan konsep syariah, hubungan manusia dalam pekerjaan sering disebut sebagai bentuk muamalah dalam kerja sama seluruh aktivitas, baik sektor industri, pertanian, pemerintahan, pendidikan, maupun sosial. ${ }^{8}$ jika dikaitkan dengan peranan MSDM yang bernilai Islami maka Bank Muamalat telah menerapkan konsep Islami pada hubungan industrialnya dengan diwujudkannya kesepakatan antara pihak manajemen dengan karyawan, sehingga terjalin tali silaturrahmi antara keduanya, hal itu dituangkan dengan bentuk perjanjian yang berjangka waktu 2 tahun, sehingga hal-hal yang mungkin terjadi itu dapat diatasi dalam jangka waktu yang disepakati. Hal yang demikian itulah yang dilakukan dalam islam yang selalu melihat dari sistem kerja yang saling menguntungkan dan memuaskan secara ekonomis, psikis, maupun sosial. Secara singkat bahwa konsep dasar dari hubungan industrial tersebut telah dirumuskan oleh Islam sebagai pola prilaku manajemen yang didasarkan pada penghormatan setiap individu sebagai potensi kapabilitas, pengalaman, hak dan kewajiban masing-masing.

Hubungan industrial atau hubungan kerjasama harus dilakukan secara amanah dan profesional sebagaimana di tegaskan dalam AlQur'an Surah Al Maidah :

Artinya

....Dan bekerjasamalah kamu dalam kebaikan dan takwa, dan janganlah bekerjasama dalam dosa dan pelanggaran (QS. Almaidah:2)

Islam menggariskan aturan berupa sistem perlindungan kerja agar tidak ada praktik pelanggaran hak dan ketidakadilan yang kemungkinan akan terjadi. Untuk hubungan industrial yang berlaku pada Bank Muamalat diatur oleh Pusat Bank Muamalat

\section{PENUTUP}

Dari keseluruhan pembahasan terdapat beberapa hal yang bisa dijadikan sebagai kesimpulan dari hasil penelitian ini, antara lain:

1. Yang dimaksud dengan implikasi atau keterlibatan MSDM yang benilai Islami pada:

a. proses perekrutan yang bernilai Islami atau rekrutmen dan seleksi syariah adalah segala kegiatan rekrutmen dan seleksi yang dilakukan harus sesuai dengan kriteria syariah. Kriteria syariah yang dimaksud adalah kriteria khusus yang disepakati oleh manajemen berdasarkan nilai-nilai dan budaya yang diterapkan oleh perusahaan. Kriteria syariah yang dimaksud misalnya muslim/muslimah, tidak merokok, berbusana muslimah, dan lain-lain. Kriteria syariah ini dapat menjadi kriteria yang

\footnotetext{
${ }^{8}$ Data laporan Bank Muamalat 2013

8 Ibid. Abu Fahmi, HRD Syariah, Gramedia, Jakarta, 2014, h. 218
} 
wajib atau mutlak tergantung dari visi dan misi serta nilai-nilai yang akan dibangun oleh perusahaan

b. pada seleksi syariah terdapat proses atau tahapan yang disebut sebagai tahapan seleksi syariah, seleksi syariah ini dapat dilakukan pada awal tahapan seleksi jika perusahaan benar-benar memiliki kebijakan bahwa test syariah adalah kriteria wajib.biasanya seleksi syariah ini berupa tes baca tulis Al Qur'an, test kemampuan keagamaan yang berhubungan dengan ibadah dan keimanan, dan lain-lain yang berkaitan dengan nilainilai Islami.

c. Pengembangan karyawan diwujudkan dengan training, training didahului dengan perencanaan selanjutnya proses pelaksanaan training itu sendiri. Pada manajemen training syariah disamping soft skill dan hard skill juga terdapat satu faktor penting yang perlu terus dijaga dan dikembangkan, yaitu syariah skill atau dapat dipahami sebagai syariah competence. Hal-hal yang berkaitan dengan syariah competence antara lain akidah, syariah dan muamalah.

d. Penilaian kinerja syariah pada prinsipnya adalah merencanakan, memantau serta mengevaluasi kompetensi syariah para karyawan. Kompetensi syariah perlu dievaluasi dan dikembangkan sejalan dengan tujuan perusahaan, yaitu bisnis dan mardhatillah.

e. Pemberian kompensasi secara Islami atau bernilai Islami disini adalah pemberian kompensasi berupa gaji atau insentif yang dapat dinilai dengan uang, dan pemberian kompensasi yang dapat berupa hadiah atau reward yang dapat memotivasi karyawan.

2. Implikasi MSDM Islami pada Bank Muamalat khususnya di kota Palopo telah melakukan atau melibatkan manajemen sumberdaya yang bernilai Islami atau yang sesuai dengan nilai-nilai Islami. Hal itu diterapkan pada:

a. Perekrutan dan seleksi yang dilakukan oleh Bank Muamalat Palopo dilakukan dengan mempertimbangkan hasil seleksi syariah, antara lain kemampuan calon karyawan dalam hal dapat membaca Al Qur'an dan menguasai perbankan syariah disamping pengalaman yang telah dimiliki oleh calon karyawan.

b. Pengembangan karyawan selalu dilakukan oleh pihak manajemen Bank Muamalat, dan diwujudkan dengan memberikan training/pelatihan kepada para karyawan.

c. Pada Bank Muamalat Palopo penerapan penilaian kinerja dan kompensasi karyawan merupakan hal yang dapat meningkatkan motivasi bagi karyawan, hal tersebut biasa berbentuk pemberian reward atau penghargaan kepada karyawan yang mencapai target tertentu. Reward paling tertinggi yang diberikan oleh Bank Muamalat kepada karyawan yang telah mencapai target adalah dengan memberangkatkan umrah bagi karyawan, disamping reward-reward yang lain, misalnya dengan memberikan bonus berupa uang yang langsung masuk ke rekening karyawan apabila karyawan tersebut dapat mencapai target yang ditentukan.

d. Hubungan industrial diatur secara langsung oleh pihak Pusat Bank Muamalat. 


\section{DAFTAR PUSTAKA}

Sumber Buku:

Al-Quran al-Karim

Arifin, Zainul, Dasar-dasar Manajemen Bank Syariah, Alfabet, Jakarta, 2003.

Bangun, Wilson, Manajemen Sumber Daya Manusia, Erlangga, Jakarta, 2012.

Daft L Richard, Managemen-manajemen, Jakarta: Salemba Empat, 2008.

Fahmi, Abu, dkk, HRD Syariah Teori dan Implementasi, Jakarta, PT. Gramedia, 2014.

Gomes, Foustino C. Manajemen Sumberdaya Manusia, Yogyakarta, Andi Offset, 2003.

Handoko, Hani, T, Manajemen Personalia dan Sumberdaya Manusia, Yogyakarta, BPFE, 1994.

Handoko, Hani, T, manajemen Personalia dan SDM, Yogyakarta. UGM, 2000.

Hasibuan, Malayu, Manajemen Dasar, pengertian dan masalah, edisi revisi, Jakarta, Bumi Aksara, 2001.

Hasibuan, Malayu, SP, Manajemen Sumberdaya Manusia, edisi revisi, Jakarta, PT, Bumi Aksara, 2010.

Husain Umar, Riset SDM dalam organisasi, Jakarta, Gramedia Pustaka Utama, 1998.

Ibrahim Ahmad, Abu Sinn, Manajemen Syariah, Sebuah kajian historis dan kontemporer, PT, Raja Grafindo Persada, Jakarta, 2008.

Indiastuti, Skripsi, Analisis Penerapan Manajemen Sumberdaya Manusia Berbasis Syariah, UIN Walisongo Semarang, 2015.

Jackson, scurler, dan Werner, pengelolaan sumber daya manusia, buku I, Ed.I; Jakarta: Salemba Empat, 2010.

Jimmy, L.Gaoll, CHR, A to Z Human Capital, Manajemen Sumberdaya Manusia, Jakarta, Grasindo, 2014.

Kartajaya, Hermawan, Muhammad Syakir Sula, Syariah Marketing, Bandung, Mizan Media Utama, 2006.

Managing The Challenge of Growth, Laporan Tahunan Annual Report, Bank Muamalat Indonesia, 2013.

Mangkunegaran, Anwar Prabu, Manajemen Sumber daya Manusia Perusahaan, Cetakan kelima, PT, Remaja Rosdakarya, Bandung, 2001.

Marwansyah, Manajemen sumberdaya manusia, edisi kedua, Bandung, Alphabeta, 2008.

Mathis,Robert,L, John H. Jackson, MSDM, Salemba Empat, Jakarta, 2001.

Nawawi, Hadari, Manajemen Sumberdaya Manusia Untuk Bisnis Yang Kompetitif, Yogyakarta, Gadjahmada University Press, 2000.

Rahmatika, Fadhilah, Skripsi, UNDIP, Semarang, 2014.

Robbins Stepen P. dan Coulter Mary, Manajemen, Ed.VIII; DKI: PT. Macanan, 2007

Siswanto, Pengantar Manajemen, Cet I; Jakarta: PT. Bumi Aksara, 2005.

Sondang, Fungsi-fungsi Manajerial, Cet.III; Jakarta: PT Bumi Aksara, 1996.

Sutanto, A.B, Dr, Budaya Perusahaan, Elex Media Competindo, Jakarta, 1997.

Tim Penulis P3EI, Ekonomi Islam, Raja Grafindo, Jakarta, 2004. 